\title{
Intrafamiliary Education and Its Disciplinary Interfaces
}

\author{
Andrea Silva1 ${ }^{\circledR}$, Simone Barros ${ }^{2}$, Rossana Moreira1 ${ }^{1}$, Ana Vieira ${ }^{1}$, Ingrid Lúcio' , Polyana Dias $^{3}$ \\ ${ }^{1}$ Federal University, Maceió, Alagoas, Brazil \\ ${ }^{2}$ Tiradentes University Center, Maceió, Alagoas \\ ${ }^{3}$ Alcides Carneiro University Hospital, Campina Grande, Brazil \\ Email: anddycord@gmail.com, simone.barros@souunit.com.br, rossanateo@hotmail.com, ana.vieira@esenfar.ufal.br, \\ ingridmll@esenfar.ufal.br, polyanamagna@hotmail.com
}

How to cite this paper: Silva, A., Barros, S., Moreira, R., Vieira, A., Lúcio, I. and Dias, P. (2020) Intrafamiliary Education and Its Disciplinary Interfaces. Open Access Library Journal, 7: e7041.

https://doi.org/10.4236/oalib.1107041

Received: November 26, 2020

Accepted: December 25, 2020

Published: December 28, 2020

Copyright $\odot 2020$ by author(s) and Open Access Library Inc.

This work is licensed under the Creative Commons Attribution International License (CC BY 4.0).

http://creativecommons.org/licenses/by/4.0/

\begin{abstract}
Living in a violent environment is a negative factor, not only because of the physical marks, but also because of the psychological consequences of an emotional and behavioral order. To identify the socioeconomic context of a group of families, in addition to the punitive educational strategies used in intrafamily education. This is a quantitative and qualitative, exploratory and descriptive study. The research was carried out through a semi-structured script on socioeconomic characteristics, notions about education and punitive measures used as an educational tool, in a municipality in the state of Alagoas. The sample consisted of 16 participants, responsible for the domestic education of adolescents. It was possible to observe that most parents/guardians used some type of corrective educational measure, such as deprivation of pleasurable activities, physical punishment or even domestic work. It is worth mentioning that the majorities are unaware of the Menino Bernardo Law, and some disagree with the State's interference in the education of their children. It was inferred that parents are unaware of the current legislation and the applicable punishments, although they recognize the need to educate themselves without violence.
\end{abstract}

\section{Subject Areas}

Interdisciplinary

\section{Keywords}

Teenager, Education, State, Family, Punishment

\section{Introduction}

The family is the social institution responsible for promoting most of the affec- 
tive and psycho-emotional development of children and adolescents [1], with parents being the first and main responsible for the formation and maintenance of affectivity, moral and ethical values such as respect for the right, opinion and religion of the other, as well as teaching good coexistence, which can be projected from the family to society [2].

It is in the family nucleus that children and adolescents experience different experiences that will serve as a basis for their maturation. However, many conflicts end up arising due to the different characteristics of each family member, especially in the adolescence period, where there is a tendency for greater questions [3].

Thus, some families have constituted the family nucleus as an environment of domestic violence, often justified as a merely disciplinary act, [4] this punitive discipline being externalized in the form of physical abuse [5].

Disciplinary encompasses several meanings, among which it is possible to point out "to submit to discipline, to obey or to yield". In addition, it constitutes a subordinate relationship with imposed or consented orders. For this reason, it can be linked to the act of punishing, punishing, correcting or rebuking and, when applied in the form of intentional punishment, it affects the body, causing what we call violence [6].

Violence consists of the intentional use of physical force, of power or in threat, against oneself, another person, group or community, which results or is very likely to cause injury, deprivation, psychological damage, developmental disability or death [7]. It does not just come from an individual in his uniqueness, but from his social context, in the way how society organizes and structures itself economically, politically and socially, making a certain group of people more vulnerable to suffering and death, constituting a social phenomenon called structural violence [8].

In the intrafamily context, it is considered as any action or omission that damages the well-being, physical, psychological integrity or the freedom and the right to the full development of another family member. This condition includes physical, psychological, sexual violence, neglect and abandonment [9]. This fact has been evident since antiquity, where mistreatment, punishment and other forms of punishment were notorious [10]. This violence can be practiced by parents and caregivers silently and has several interfaces, among them, the perspective of educational or punitive correction justified by emotional lack of control, family difficulties and financial and social difficulties, leading them to practice punishments that, in turn, they result in emotional and physical suffering; cruel or degrading treatment; humiliations; threats and ridicules [1] [11].

Thus, cohabiting in a violent environment is a negative factor, not only due to physical marks, psychological consequences of emotional and behavioral order, but also low self-esteem, anguish, insecurity, crying, depression, anxiety, problem of self-control, inhibition, isolation, behaviors exaggerated, aggressiveness, delinquency, consumption of alcohol and drugs of abuse, post-traumatic stress 
disorder and suicide [5].

Among the studies carried out in the field of social policies in Brazil, there is a set of studies that propagate the lack of an effective social protection system until 1990, due to the insufficient service given the sociocultural and economic abyss existing in society or even the fragile recognition of civil, political and social rights in our political culture and in the incipient democratic state we have. However, in recent decades, progress has been made in creating legislation and protection networks for children and adolescents exposed to social vulnerability and in situations of violence [12]. As an example, we have the creation of the Doctrine of Integral Protection (1973), the Universal Declaration of Human Rights (1948) and the Federal Constitution of 1988, which favored the strengthening of the movement in defense of the rights of children and adolescents. [12] [13] [14].

Subsequently, the Child and Adolescent Statute (1990) and, more recently, Law No. 13.010 of 2014, known as the Menino Bernardo Law [15] [16] [17], allowed those parents who used forms of violence in home education could respond civilly or criminally. Some of these measures may result in the aggressor being referred for psychological treatment, detoxification, or even to the support center for vulnerable families; family orientation courses or programs [15] [17], as well as severe measures such as loss of custody of the child, removal of guardianship and suspension or removal of family power; and, in the last case, confinement, which can vary from 3 months to 12 years [15].

The experience lived by the children in the education offered by the parents, and the social context in which the parents lived and were educated, contribute to passing on the same educational values received in a violent context, as a form of family education, through punishment as a discipline or corrective measure [1] [16] [18]. Causing damage that reverberates throughout life, impairing social, affective and behavioral interactions [8] [18].

Reflecting the relationship between intrafamily education, violence and its consequences; we seek to answer the following questions: What is the socioeconomic context of the families surveyed and what are the punitive educational strategies imposed on children?

Based on this assumption, the present study aimed to identify the socioeconomic context of a group of families, in addition to the punitive educational strategies imposed on intrafamily education.

\section{Materials and Method}

This is a quantitative-qualitative, exploratory and descriptive research, conducted from June to August 2019, with 16 participants (parents or legal guardians for the domestic education of adolescents). Excluding caregivers without a legal relationship with adolescents; parents and/or caregivers of children under 18 years of age, and parents who did not live with their children. The research was organized in two phases, an exploratory one, through the assumptions and 
questions that guided the object of the research and subsequent treatment of the data. Thus, we sought to answer the following guiding questions: What is the socioeconomic context of the families surveyed and what are the educational strategies of a punitive nature used by them? Data were collected after signing the Free and Informed Consent Term (TCLE) at the residents' homes, in the community of Romeiros located in the center of the municipality of Cajueiro-AL, a neighborhood of great social vulnerability.

Data collection was carried out through a semi-structured interview composed of 16 open and dichotomous questions, guided by a structured script in the following dimensions: 1) socioeconomic conditions; 2) responsibility for the home and the education of children, knowledge about education, measures adopted as an educational tool; 3) use of punishment and knowledge about violence and legislation to protect adolescents.

The stage of selection and treatment of the collected data was organized in: ordering, classification and analysis of the information. In this first stage, a faithful transcription of the content obtained in the recording was made, with subsequent reading for the organization of the speeches, through the typification process, in which the phrases and texts were grouped by their common sense. Next, interpretation and inferences were carried out through the correlation with the theoretical framework and quantification and numerical analysis using graphs and tables. The speeches were transcribed and designated by fictitious names of the participants.

This study was approved by the Research Ethics Committee of the Federal University of Alagoas, under protocol 3,426,280, obeying the rules defined by resolution CNS 466/17.

\section{Results and Discussion}

The survey had a total of 16 participants, whose ages ranged from a minimum of 31 years to 57 years, with a predominance of females with 15 (94\%). As for education level, 1 (43\%) have incomplete fundamental level. While $6(37.5 \%)$ have a family income $\geq 2$ salaries (see Table 1 ).

With regard to responsibilities for the home and family education, it is clear that the education that has only the woman as the responsible corresponds to 9 (56\%) participants. It appears that the responsibility for the education of children is still in the mother's domain, where only one father was considered responsible for the education of his children; however, it was possible to observe the sharing of this responsibility between both, registered in $31 \%$ of the participants.

This relationship is justified by the inheritance of the family patriarchate from the colonial period, which was structured in relations of social and gender domination, in which men are placed in a higher position than women and children. Women are assigned the role of housewives and men, the obligation to be the head of the house and provide for the family [17]. 
Table 1. Socioeconomic profile of participants, 2019.

\begin{tabular}{|c|c|c|c|c|c|}
\hline \multirow{2}{*}{ Variables } & \multicolumn{4}{|c|}{$\mathrm{n}(\%)$} & \multirow{2}{*}{$\begin{array}{l}\text { Family } \\
\text { income }\end{array}$} \\
\hline & \multicolumn{2}{|c|}{ Age } & \multirow[t]{2}{*}{ Genre } & Education & \\
\hline & & & & Unschooled & $<1$ minimum wage \\
\hline & & & & $3(18.7 \%)$ & $2(12.5 \%)$ \\
\hline & $30-40$ & $6(37.5 \%)$ & & Incomplete fundamental 7 (43.7\%) & $\geq 1=5(31.2 \%)$ \\
\hline & $41-50$ & $8(50.0 \%)$ & Male $1(06 \%)$ & Complete fundamental 4 (25.0\%) & $\geq 2=6(37.5 \%)$ \\
\hline & $51-60$ & $2(12.5 \%)$ & Feminine 15 (94\%) & Incomplete medium 0 (00.0\%) & $3-5=1(06.3 \%)$ \\
\hline & $61-70$ & $0(00.0 \%)$ & & Complete medium $1(06.3 \%)$ & $+5=0(00.0 \%)$ \\
\hline & & & & Incomplete higher $1(06.3 \%)$ & Did not inform \\
\hline & & & & Complete higher $0(0.00 \%)$ & $2(12.5 \%)$ \\
\hline
\end{tabular}

Regarding the type of measure applied in the face of a conflict situation between parents and children, 14 (87\%) of the interviewees stated that they use dialogue as a strategy to resolve the impasse. None of the interviewees reported leaving their child free to do whatever they want and $2(12.5 \%)$ said they applied a punishment as a corrective education tool.

When asked about the type of punishment they would apply if there was a need, 7 (44\%) stated that they deprive their child of the activities and objects they like most. A significant number, 5 (31\%), would apply physical punishment, 3 (19\%) would apply dialogue and 1 (6\%) did not answer the question (see Table 2).

Parents can use inductive and coercive discipline. The first is characterized by the use of communication, interaction between parents and children, explanations about the consequences of their acts, use of rules and values aiming at changing the child's behavior [5].

With regard to coercive discipline, it is in this that in fact the imposition by the power of the parents is used, through the use of physical force, in the form of punishment and imposition through verbal authoritarianism with insults and threats [19] [20].

[...] forbid the things he likes. [...] I think so, if I have a friendship with a colleague, I draw. If I have a cell phone, I'll take it. Are you understanding? If you like cell phones, tie [...]

Until you obey, that business is not released. Because there is no use hitting. What will it do? Anything. I take the objects out of his taste. I removed his cell phone for three years (Cleide, 47 years old).

It is evident in Cleide's speech that some parents consider the removal of a pet object and the prohibition of activities that their children enjoy most as an effective method of education. Physical punishment is still used, but there are few parents who said they still use it, 3 (31\%).

When asked about what physical punishment is, $5(31 \%)$ of the interviewees did not know how to answer and 11 (69\%), defined physical punishment as "a form of aggression, hitting, pinching, beating ... a way of causing bodily pain". 
Table 2. Types of punishments applied by parents, 2019 .

\begin{tabular}{ccccc}
\hline \multirow{2}{*}{ Variables } & \multicolumn{5}{c}{$\mathrm{n}(\%)$} \\
\cline { 2 - 5 } & $\begin{array}{c}\text { Physical } \\
\text { punistiment }\end{array}$ & Dialogue & $\begin{array}{c}\text { Withdrawal of } \\
\text { personal effects }\end{array}$ & $\begin{array}{c}\text { They did } \\
\text { not answer }\end{array}$ \\
\hline $5(31.0 \%)$ & $3(19.0 \%)$ & $7(44.0 \%)$ & $1(6.0 \%)$ \\
\hline
\end{tabular}

One interviewee reported her impression of punitive education using pain for revisiting memories of punishments suffered in her childhood:

The way I was raised, I would never, never raise my child. If I don't even like to talk there (cry ... Pause). My aunt would ground me on my knees on top of those little stones that she uses to build a house and with a stool on her head ... hey, I suffered, you see. It was from three hours to five in the afternoon. I suffered a lot saw. That's why I spent that I never do with my son, ever! And my way of creating worked. It is no use hitting because you create a revolted, suffering person, you know? (crying ... Pause) it's no use raising a child and hitting, right? (Cleide, 47 years old).

In this interviewee's speech, the expression of personal experience and the emotional marks and psychological traumas that she has experienced throughout her life is clearly observed, which motivates her to use positive educational measures and not reproduce the violence suffered.

Another participant highlighted the importance of legislation aimed at protecting children and adolescents and its effectiveness, as it makes explicit the concern with the presence of the tutelary council:

I think ... I don't know ...! The mother can no longer draw blood. No more, or the Guardian Council knocks on the door. You have to punish today, without being a heavy punishment (Josefa, 44 years old).

With regard to the abuse of power applied in the form of psychological violence, none of the participants was able to perceive them in the interview. In this matter, it was possible to perceive the population's limitation related to knowledge about the types of punishment and violence, as they recognize punishment only in its physical form. Regarding the application of punishment, 2 (13\%) admitted to having applied some of the mentioned forms of punishment.

The lack of knowledge about what punishment is and its consequences can lead parents to practice it, especially in the form of humiliation with isolation from the child, which constitutes the type of psychological punishment. This is what they consider disciplinary punishment:

You will stay in the room, grounded (Josefa, 44 years old).

When asked about what type of punishment they would apply in the face of a situation that required it, 12 (75\%) of the interviewees preferred the application of dialogue in a conflict situation. When asked whether punishment is a way of educating, 13 (81\%) considered it an educational method. 
All parents (100\%) believe that it is their obligation to enroll their children in school. They also believe that children cannot decide on their own lives (see Table 3).

Up to 17 years old they cannot decide their life, only the mother. Because they don't have much thought to decide, no. Only when he is older (Cícera, 54 years old).

In relation to the limit between punishment and violence, for $100 \%$ of the interviewees, the punishment goes beyond the limits and turns into violence when physical and psychological abuse occurs, such as: hitting, shouting, threatening to be expelled from home, beating. As can be seen in the statements of the following interviewees:

Like a punishment for leaving without eating, without eating, without drinking water. This is horrible (Santina, 40 years old).

Even though they know that punishing and transcending beyond punishment is wrong, parents practice it because they believe they punish to correct their child and think they are doing good, although they admit that it is a loss of control of the situation.

As for the interviewees' knowledge about the Menino Bernardo Law, it was observed that 15 (94\%) are unaware. The population does not have legal knowledge about the rights of children and adolescents and the punitive measures adopted in their homes are empirical. When answering, they think that the state should not decide on the parents' authority not to impose physical punishment on their children, 3 (19\%):

I think not! We parents have a duty to raise and educate our children, in our own way ... I think that we have to solve things ourselves (Helena, 41 years old).

Of the interviewees who support the State's intervention in defense of children and adolescents in relation to physical punishment, they argue that parents do not have the right to use violence as an educational measure and noted that, after the ECA and the Guardianship Council were in force, there is a fear of parents when using coercive education as they have to answer for their actions to counselors.

Table 3. Parents' knowledge and opinion about their children's education, 2019.

\begin{tabular}{lccc}
\hline \multicolumn{1}{c}{ Variables } & \multicolumn{2}{c}{$\mathrm{n}(\%)$} & \\
& & Nes & Sot \\
\hline Is it your parents' duty to enroll your child in a school? & $16(100 \%)$ & $00(000 \%)$ & $00(000 \%)$ \\
For you, housework is a how to educate your children? & $14(87.5 \%)$ & $02(12.5 \%)$ & $00(000 \%)$ \\
Do you think that children and adolescents can decide about their own lives? & $01(6.2 \%)$ & $15(93.7 \%)$ & $00(000 \%)$ \\
Do you believe that punishment is a way of educating? & $12(75.0 \%)$ & $03(18.7 \%)$ & $01(6.2 \%)$ \\
\hline
\end{tabular}


I think so because parents believe they have the right to use physical violence to get what they need and expect from their children. (Joana, 40 years old).

Yes, it can, because after the Guardianship Council children's suffering has been avoided (Luzia 39 years old).

It is also possible to perceive the acceptance of the social hierarchy and the power relationship established by government agencies. As in the following speech:

It has power because the government is governed by the rich (João, 42 years old).

Educational activity is an arduous task with a marked degree of complexity, which often differs from what is expected by parents, who get frustrated when they expect their children to be like them, or even reproduce what they have ceased to be. The context is also considered, with the stress generated by tiring activity and, often, by the lack of conditions to create and educate them [11].

In the respondents' responses, there are several forms of parental education and promotion of parental autonomy over them, such as: in the authoritarian style, where there is a balanced use of dialogue and the prudent use of the penalty, as well as the use of their relationship of power for the promotion of autonomy, demonstrating the consequences generated by the child's behavior. Thus, intrafamily violence is a form of domination by one over the other [8].

In addition, education is an important weapon against violence, because through it the barriers of social inequality are broken. Education can be liberating and oppressive, and should be used as a practice of freedom, conceived in a reciprocal way, through interaction and dialogue between the subjects involved in the demonstration of affection and affection from parents, and in the transfer of morals and ethics. This process is called parenteral styles [16] [20].

Liberating education is understood as one that prioritizes dialogue and not the imposition to be obeyed, in which interaction and problematization of the reality experienced is allowed as a practice for freedom and for good family coexistence without violence [21].

Another strategy to be considered is positive educational practice, favoring human development through well-being and self-control, in which problem solving comes from a mutual approach, interrelating the traditional and appreciative approach, identifying the problem and the assessment of positive points [22].

Thinking to act in the best way when using punishment as an educational tool, these parents are mistaken, because what they achieve is obedience through fear and pain [16].

The increasing number of situations of violence involving adolescents and young people is often induced by the way in which family values are transmitted, as these are the values that will determine whether or not these young people's behavior will be at risk [12]. 
It is with the family that children experience the first routine organization, follow rules and experience situations of flexibility. And it is this experience that will influence the young person's behavior, even in adulthood, to reproduce what he has learned throughout his life [1].

As for adolescence, there is an inverse relationship between positive values and risky behavior, so it is necessary to offer more positive values in the family routine so that there is less risky behavior among young people [23].

The formation of the awareness that it is necessary to use social, ethical and moral values in a positive way to prevent violence, resolve conflicts and for a culture of peace; here defined as a culture based on tolerance, sharing, respect for diversity and pluralism and the opinion of the other are instruments that must be used [19].

It is through the culture of peace that critical reasoning is awakened that makes human beings capable of thinking about their actions and their actions and through education they are able to transform themselves as human beings and be able to improve their relationships and the environment in which they live. This is transformative education, capable of reducing violence and based on harmony in peace [7].

\section{Final Considerations}

When approaching this theme, it was observed that there are several problems with regard to information on the interrelationship between the legal rights of children and adolescents.

It is possible to perceive that the reduction of risk behaviors with a view to reducing the levels of violence in home education is not only the family's responsibility, as the family itself can also live at risk, it is, above all, the responsibility of the State.

Thus, it is extremely important to encourage the expansion of positive educational practices, based on affective relationships and intra-family dialogue, with a view to improving health, well-being and the healthy growth and development of children and adolescents.

Thus, this study described relations between theoretical and dialogical constructs, however its limitation is due to the small sample size, allowing considering the results found only for the population in question.

Along the development of the research, related problems were identified that would allow the development of other studies to broaden the understanding of the phenomenon studied, or to seek empirical confirmation of the results obtained. Therefore, it is recommended that parenting styles of education are better explored in future research.

\section{Conflicts of Interest}

The authors declare that there is no conflict of interest regarding the publication of this article. 


\section{References}

[1] Torres, E.A., Marques, W.L.S., Fontanele, Z.V.C. and Sales, M.C.V. (2015) What Parents Think about Child Violence. Journal of the Health Sciences Institute, 33, 160-163.

https://www.unip.br/presencial/comunicacao/publicacoes/ics/edicoes/2015/02_abr-j un/V33_n2_2015_p160a163.pdf

[2] Brazil (2018) Law No. 13,772, of December 19, 2018. Amends Law No. 11,340, of August 7, 2006 (Law Maria da Penha), and Decree-Law No. 2,848, of December 7, 1940 (Penal Code), to Recognize That the Violation of Women's Intimacy Constitutes Domestic and Family Violence and to Criminalize the Unauthorized Registration of Content with a Nudity Scene or Sexual or Libidinous Act of an Intimate and Private Nature. Official Gazette of the Union, 19 Dec 2018.

[3] Neto, F.R.G.X., Santos, M.P.S., Nicolau, M.F.A., Cunha, I.C.K.O. and Machado, M.H. (2018) Experiences of Nurses in the Family Health Strategy in Caring for Children and Adolescents Who Are Victims of Domestic Violence. Essentia (Sobral), 19, 40-52. http://essentia.uvanet.br/index.php/ESSENTIA/article/view/162

[4] Zanim, C.S. and Vendruscolo, T.S. (2018) Violence against Children and Adolescents, a Matter of Education. Social Work \& Reality, 24, 9-29.

https://ojs.franca.unesp.br/index.php/SSR/article/view/2487/2193

[5] Garbin, C.A.S., Araújo, P.C., Donine, A.L.M.A. and Garbin, A.J.I. (2017) Evaluation of Educators' Knowledge about Intrafamily Education: An Approach Carried out in Municipal Elementary Schools. Revista de Educação Popular, 16, 70-81. https://doi.org/10.14393/REP_v16n22017_art05

[6] Brazil Constitution (1988) Constitution of the Federative Republic of Brazil. Federal Senate, Brasília.

[7] De Sousa Moreira, L. and Branco, A.U. (2017) Culture of Peace, Morality and Civic virtues: Contributions from Cultural Psychology. Psicologia Argumento, 30, 161-170.

https://periodicos.pucpr.br/index.php/psicologiaargumento/article/view/20455

[8] Reis, D.M., Silver, L.C.G. and Parra, C.R. (2018) The Impact of Intrafamily Violence on Children's Psychic Development.

https://www.psicologia.pt/artigos/textos/A1253.pdf

[9] Barreto, M.J. and Rabelo, A.A. (2015) The Family and the Challenging Role of Parents of Adolescents in Contemporary Times. Thinking Families, 19, 34-42. http://pepsic.bvsalud.org/scielo.php?script=sci_arttext\&pid=S1679-494X201500020 0004

[10] Vieira, A.M. (2015) Intra-Family Violence: A Psychoanalytic View of the Possible Consequences on Child Development. Faculty of Education and Sciences, Brasília University Center, Brasília.

[11] Nunes, A.J. and Sales, M.C.V. (2016) Violence against Children in the Brazilian Scenario. Ciênc Saúde Colet, 21, 871-880. https://doi.org/10.1590/1413-81232015213.08182014

[12] Brazil (1940) Decree-Law No. 2,848, of December 7, 1940. Penal Code, Official Gazette of the Union, 7 December 1940.

[13] Brazil (2014) Law No. 13,010, of June 26, 2014. Amends Law No. 8,069, of July 13, 1990 (Statute of Children and Adolescents), to Establish the Right of Children and Adolescents to Be Educated and Cared for without Use Physical Punishment or Cruel or Degrading Treatment, and Amends Law No. 9,394, of December 20, 1996. Diário Oficial da União, 26 June 2014. 
[14] Perez, J.R.R. and Passone, E.F. (2010) Social Policies for Assisting Children and Adolescents in Brazil. Cadernos de Pesquisa, 40, 649-673. https://doi.org/10.1590/S0100-15742010000200017

[15] Brazil, Presidency of the Republic (1990) Law No. 8,069, of July 13, 1990. Provides for the Statute of Children and Adolescents and Provides Other Measures. Federal Official Gazette, 13 Jul 1990, Section 1.

[16] De Almeida Maia, F. and Soares, A.B. (2019) Differences in Parenting Practices of Fathers and Mothers and the Perception of Adolescent Children. Estudos Interdisciplinares em Psicologia, 10, 59-82. http://dx.doi.org/10.5433/2236-6407.2019v10n1p59

[17] Borsa, J.C. and Nunes, M.L.T. (2011) Psychosocial Aspects of Parenting: The Role of Men and Women in the Nuclear Family. Psicologia Argumento, 29, 31-39. https://periodicos.pucpr.br/index.php/psicologiaargumento/article/view/19835/191 $\underline{41}$

[18] Garbin, C.A.S., Lima de, T.J.V., Ísper Garbin, A.J., Rovida, T.A.S. and Saliba, O. (2015) Knowledge and Perception of Early Childhood Educators on Violence. Revista Ciência Plural, 1, 37-47. https://periodicos.ufrn.br/rcp/article/view/7614

[19] Sousa, K.R. and Kerbauy, M.T.M. (2017) Quanti-Qualitative Approach: Overcoming the Quantitative-Qualitative Dichotomy in Research in Education. Education and Philosophy, Uberlândia, 31, 21-44.

[20] da Silva, P.A., Lunardi, V.L., da Silva, M.R.S. and Lunardi Filho, W.D. (2009) The Notification of Intrafamily Violence against Children and Adolescents in the Perception of Health Professionals. Ciência, Cuidado e Saúde, 8, 56-52.

[21] Brighente, M.L. and Mesquita, P. (2016) Paulo Freire: From the Denunciation of Banking Education to the Announcement of a Liberating Pedagogy. Pro-Posições, 27, 155-177. https://dx.doi.org/10.1590/0103-7307201607909

[22] Sgorla, K. and Nicodem, M.F.M. (2018) Positive Education: The Teaching of Well-Being and Its Emotional and Cognitive Implications. Pleiade, 12, 42-59. https://pleiade.uniamerica.br/index.php/pleiade/article/view/488

[23] Toni, C.G.D.S. and De Matos Silvares, E.F. (2013) Parental Educational Practices and Health and Risk Behaviors in Adolescence: A Predictive Model. Psicologia Argumento, 31, 457-471. 